\title{
Re-evaluation of acid-base prediction rules in patients with chronic respiratory acidosis
}

\author{
Tereza Martinu MD ${ }^{1,2}$, Dick Menzies MD MSc ${ }^{1}$, Sandra Dial MD MSc ${ }^{1}$
}

T Martinu, D Menzies, S Dial. Re-evaluation of acid-base prediction rules in patients with chronic respiratory acidosis. Can Respir J 2003;10(6):311-315.

RATIONALE: The prediction rules for the evaluation of the acidbase status in patients with chronic respiratory acidosis, derived primarily from an experimental canine model, suggest that complete compensation should not occur. This appears to contradict frequent observations of normal or near-normal $\mathrm{pH}$ levels in patients with chronic hypercapnia.

METHODS: Linear regression analysis was used to estimate the relationships between arterial $\mathrm{pH}$, bicarbonate and partial pressure of carbon dioxide $\left(\mathrm{PCO}_{2}\right)$ from 18 separate arterial blood gas measurements in 18 clinically stable outpatients with chronic hypercapnic respiratory failure from chronic obstructive lung disease, and without clinical conditions or medications likely to cause a primary metabolic alkalosis. RESULTS: The $\mathrm{PCO}_{2}$ ranged from $45 \mathrm{mmHg}$ to $77 \mathrm{mmHg}$, and $\mathrm{pH}$ ranged from 7.37 to 7.44 . In only three of the arterial blood gas measurements were the $\mathrm{pH}$ values lower than 7.38. From the regression equations derived from these measurements, the $\mathrm{pH}$ decreased by 0.014 for each $10 \mathrm{mmHg}$ increase in the $\mathrm{PCO}_{2}$, and the bicarbonate level increased by $5.1 \mathrm{mmol} / \mathrm{L}$. These values are quite different from a decrease in $\mathrm{pH}$ of 0.03 and an increase in bicarbonate of $3.5 \mathrm{mmol} / \mathrm{L}$ predicted using the rules derived from the canine model.

CONCLUSIONS: In patients with chronic stable hypercapnia, acid-base compensatory mechanisms appear to be more effective than would be predicted using the classic rules.

Key Words: Acid-base equilibrium; Chronic obstructive pulmonary disease; Hypercapnia; Respiratory acidosis

$\mathrm{H}$ ydrogen ion concentration is a critical determinant of many physiological functions (1). For this reason, the blood $\mathrm{pH}$ is very tightly regulated and normally ranges between 7.38 and 7.42 in humans and many other species (2). Many physiological systems are involved in this regulation, including the respiratory system and kidneys, as well as red blood cells, proteins and the bicarbonate buffering system within the blood.

The current prediction equations used to assess the acidbase status in patients with chronic respiratory acidosis were derived from experiments in dogs (3-5). In these experiments, large changes (greater than $20 \mathrm{mmHg}$ ) in the partial pressure of carbon dioxide $\left(\mathrm{PCO}_{2}\right)$ were induced and
La réévaluation des règles de prédiction acidobasique chez les patients atteints d'une acidose respiratoire chronique

JUSTIFICATION : Les règles de prédiction pour l'évaluation de l'état acidobasique des patients atteints d'une acidose respiratoire chronique, principalement dérivées d'un modèle canin expérimental, laissent supposer l'impossibilité théorique d'une compensation complète. Ce constat semble être en contradiction avec les observations fréquentes de taux de $\mathrm{pH}$ normal ou quasi-normal chez les patients atteints d'hypercapnie chronique.

MÉTHODOLOGIE : Une analyse de régression linéaire a été utilisée pour évaluer le lien entre le $\mathrm{pH}$ artériel, le bicarbonate et la pression partielle du dioxyde de carbone $\left(\mathrm{PCO}_{2}\right)$ à partir de 18 gazométries artérielles distinctes prises chez 18 malades externes cliniquement stables atteints d'insuffisance respiratoire hypercapnique chronique causée par une bronchopneumopathie chronique obstructive ne souffrant pas de pathologie clinique ou ne prenant pas de médicaments susceptibles de causer une alcalose métabolique.

RÉSULTATS : Le $\mathrm{PCO}_{2}$ variait entre $45 \mathrm{mmHg}$ et $77 \mathrm{mmHg}$ et le $\mathrm{pH}$, entre 7,37 et 7,44. Seules trois gazométries artérielles s'associaient à un $\mathrm{pH}$ inférieur à 7,38. D'après les équations de régression dérivées de ces mesures, le pH diminuait de 0,014 pour $10 \mathrm{mmHg}$ d'augmentation de $\mathrm{PCO}_{2}$, et le taux de bicarbonate augmentait de $5,1 \mathrm{mmol} / \mathrm{L}$. Ces valeurs differrent beaucoup de la diminution de $\mathrm{pH}$ de 0,03 et de l'augmentation de bicarbonate de $3,5 \mathrm{mmol} / \mathrm{L}$ prédites d'après les règles dérivées du modèle canin.

CONCLUSIONS : Chez les patients atteints d'hypercapnie chronique stable, les mécanismes acidobasiques compensatoires semblent plus efficaces qu'on le prédirait au moyen des règles classiques.

sustained for a maximum of seven days. However, this is not the typical rate of increase, nor duration, of hypercapnia in patients with slowly progressive diseases such as chronic obstructive pulmonary disease (COPD). In these patients, normal or near-normal $\mathrm{pH}$ values have been observed (6). These are often attributed to the presence of a metabolic alkalosis due to diuretics and/or corticosteroids, superimposed on the primary respiratory acidosis. In four earlier studies (7$10)$, the degree of acid-base compensation was greater in patients with chronic respiratory acidosis than that described in the canine experiments. However, the patients studied were hospitalized and clinical stability was not defined (10),

${ }^{1}$ Respiratory Epidemiology Unit, Montreal Chest Institute, McGill University, Montreal, Quebec; ${ }^{2}$ Department of Medicine, Duke University Medical Center, Durham, North Carolina, USA

Correspondence and reprints: Dr Sandra Dial, Montreal Chest Institute, 3650 St Urbain, Room K1.14, Montreal, Quebec H2X 2 P4.

Telephone 514-842-1231 ext 32336, fax 514-843-2083, e-mail sandra.dial@mcgill.ca 
or was defined as elevated $\mathrm{PCO}_{2}$ that was stable for only three days (7-9). It is possible that, as in the dog experiments, the measurements were made before there was complete acidbase compensation.

The present study was performed to re-evaluate the relationships between the arterial $\mathrm{pH}, \mathrm{PCO}_{2}$ and bicarbonate levels in patients with chronic respiratory acidosis who were clinically stable for at least one month.

\section{METHODS}

Patients were considered eligible if they had arterial blood gas analyses performed as outpatients at the Montreal Chest Institute, Montreal, Quebec, had COPD or cystic fibrosis (CF) and were hypercapnic (arterial $\mathrm{PCO}_{2}$ of $45 \mathrm{mmHg}$ or higher). Patients were excluded if they had taken diuretics, oral steroids or angiotensin-converting enzyme inhibitors, or had renal failure in the month before the arterial blood gas sampling. This study was approved by the Ethics Committee of the Montreal Chest Institute.

Eligible patients were defined as clinically stable at the time of the arterial blood gas sampling if they met the following criteria: the arterial blood gas analysis was performed during a routinely scheduled outpatient visit; the blood gas analysis was done to assess need for home oxygen or rehabilitation; there were no new respiratory symptoms or change in medications for at least one month before and after the blood gas analysis; and they were considered stable by their primary physician.

Arterial blood gas results were also extracted from patients who were eligible but not clinically stable at the time, as defined above. These patients were defined as clinically unstable and their blood gas analyses were used as observations for comparison with the observations from clinically stable patients.

\section{Data collection}

Data abstracted retrospectively from the patients' charts included age, sex, comorbid diseases, medications, diagnosis, use of home oxygen, baseline pulmonary function tests and all results of outpatient arterial blood gas measurements. Clinical stability was assessed from the data collected by one of the investigators, without knowledge of the arterial blood gas results.

\begin{tabular}{|c|c|}
\hline Number of subjects & 18 \\
\hline \multicolumn{2}{|l|}{ Diagnosis (n) } \\
\hline COPD & 4 \\
\hline CF & 14 \\
\hline \multicolumn{2}{|l|}{ Age in years (mean $\pm S D$ ) } \\
\hline COPD & $64.6 \pm 8.3$ \\
\hline CF & $28 \pm 4.9$ \\
\hline Sex - number of males $(\%)$ & $11(61 \%)$ \\
\hline Number on long term oxygen therapy (\%) & $7(49 \%)$ \\
\hline Mean baseline forced expiratory volume in $1 \mathrm{~s} \pm \mathrm{SD}(\mathrm{L})$ & $0.71 \pm 0.53$ \\
\hline
\end{tabular}

The arterial blood gas measurements were analyzed using a Bayer 800 series analyzer (Bayer, Canada). This instrument provides linear measurements for the $\mathrm{PCO}_{2}$ in the range of $5 \mathrm{mmHg}$ to $250 \mathrm{mmHg}$ (machine specification). To ensure accuracy of the measurements, the machines are calibrated using three controls on a daily basis; the results of quality assessments over the study period are listed below.

$$
\begin{aligned}
& \text { Control } 1 \text { - Expected } \mathrm{pH} \text { range: } 7.13 \text { to } 7.17 \text {; } \\
& \text { Measured ( } \pm \text { SD): } 7.147 \pm 0.003 \\
& \text { Expected } \mathrm{PCO}_{2} \text { range: } 68.3 \text { to } 81.1 \mathrm{mmHg} \\
& \text { Measured ( } \pm \text { SD): } 72.5 \pm 1.1 \mathrm{mmHg} \\
& \text { Control } 2 \text { - Expected } \mathrm{pH} \text { range: } 7.341 \text { to } 7.381 \\
& \text { Measured }( \pm \text { SD): } 7.36 \pm 0.002 \\
& \text { Expected } \mathrm{PCO}_{2} \text { range: } 36.5 \text { to } 46.5 \mathrm{mmHg} \\
& \text { Measured ( } \pm \text { SD): } 40.7 \pm 0.2 \mathrm{mmHg} \\
& \text { Control } 3 \text { - Expected } \mathrm{pH} \text { range: } 7.543 \text { to } 7.595 \\
& \text { Measured }( \pm \text { SD): } 7.569 \pm 0.002 \\
& \text { Expected } \mathrm{PCO}_{2} \text { range: } 20.6 \text { to } 24.6 \mathrm{mmHg} \\
& \text { Measured ( } \pm \text { SD): } 23.6 \pm 0.3 \mathrm{mmHg}
\end{aligned}
$$

The within-run precision was within $2 \%$ at all levels. The bicarbonate levels were calculated from the arterial $\mathrm{PCO}_{2}$ and $\mathrm{pH}$ using the Henderson-Hasselbalch equation.

\section{Data analysis}

To estimate the relationship between $\mathrm{PCO}_{2}$ and arterial $\mathrm{pH}$, bicarbonate and hydrogen ion concentrations by comparison with other studies, linear regression was performed using SAS (SAS Institute, USA).

\section{RESULTS}

Arterial blood gas analyses were performed on 18 eligible patients who were deemed to be clinically stable at the time of sampling. As shown in Table 1, four patients had CF and 14 had COPD. Although these two groups were very different in terms of age, their arterial blood gas results and acid-base compensations were very similar. Therefore, results from patients with these two diagnoses were combined in all tables and figures. The overall average $\mathrm{pH}$ was 7.40 and $\mathrm{PCO}_{2}$ was $58 \mathrm{mmHg}$. The lowest observed $\mathrm{pH}$ was 7.37 ; a $\mathrm{pH}$ lower than 7.38 was measured in only three instances (17\%) (Table 2).

The slope of the relationship between arterial $\mathrm{PCO}_{2}$ and $\mathrm{pH}$ estimated from regression is shown in Figure 1. Similarly, the estimated relationship between arterial $\mathrm{PCO}_{2}$ and bicarbonate is shown in Figure 2. As shown in Table 3, an increase of $10 \mathrm{mmHg}$ in the $\mathrm{PCO}_{2}$ was associated with a decrease of only 0.014 in the $\mathrm{pH}$ and an increase of $5.1 \mathrm{mmol} / \mathrm{L}$ in the bicarbonate level. Using the regression coefficients and intercept, in a stable patient with a $\mathrm{PCO}_{2}$ of $55 \mathrm{mmHg}$, one could predict that the $\mathrm{pH}$ would be 7.40 with a bicarbonate level of $33 \mathrm{mmol} / \mathrm{L}$.

There were 17 blood gas samples taken from 17 eligible patients who did not meet the criteria of clinical stability at the time of arterial blood gas sampling. A test performed to evaluate whether the two regression curves were statistically significantly different almost reached statistical significance $(P=0.06)$. The estimated relationships between arterial $\mathrm{pH}$, bicarbonate and $\mathrm{PCO}_{2}$ in the unstable group were very similar to those obtained 
TABLE 2

Characteristics and arterial blood gas values for stable hypercapnic patients

\begin{tabular}{|c|c|c|c|c|c|}
\hline Patient & Diagnosis & $\begin{array}{c}\text { Age } \\
\text { (years) }\end{array}$ & pH & $\begin{array}{c}\mathrm{PCO}_{2} \text { level } \\
(\mathrm{mmHg})\end{array}$ & $\begin{array}{l}\text { Bicarbonate } \\
\text { level (mmol/L) }\end{array}$ \\
\hline 1 & COPD & 71 & 7.41 & 46 & 29 \\
\hline 2 & COPD & 80 & 7.37 & 53 & 30 \\
\hline 3 & COPD & 67 & 7.38 & 67 & 39 \\
\hline 4 & COPD & 60 & 7.41 & 51 & 31 \\
\hline 5 & COPD & 62 & 7.39 & 69 & 41 \\
\hline 6 & COPD & 72 & 7.43 & 48 & 31 \\
\hline 7 & COPD & 54 & 7.4 & 71 & 42 \\
\hline 8 & COPD & 54 & 7.39 & 59 & 35 \\
\hline 9 & COPD & 67 & 7.41 & 62 & 38 \\
\hline 10 & COPD & 68 & 7.39 & 68 & 40 \\
\hline 11 & COPD & 74 & 7.44 & 47 & 31 \\
\hline 12 & COPD & 66 & 7.38 & 52 & 30 \\
\hline 13 & COPD & 54 & 7.43 & 52 & 34 \\
\hline 14 & COPD & 55 & 7.41 & 51 & 30 \\
\hline 15 & CF & 27 & 7.42 & 47 & 30 \\
\hline 16 & CF & 22 & 7.39 & 59 & 36 \\
\hline 17 & CF & 28 & 7.37 & 77 & 45 \\
\hline 18 & CF & 34 & 7.37 & 61 & 33 \\
\hline \multicolumn{2}{|c|}{ COPD patients $(n=14)^{*}$} & \multicolumn{2}{|c|}{$64.6 \pm 8.37 .40 \pm 0.02$} & $57 \pm 9.0$ & $34 \pm 4.8$ \\
\hline \multicolumn{2}{|c|}{ CF patients $(n=4)^{\star}$} & \multicolumn{2}{|c|}{$27.8 \pm 4.97 .39 \pm 0.02$} & $61 \pm 12.3$ & $36 \pm 6.5$ \\
\hline
\end{tabular}

*Values expressed as mean $+S D$. CF Cystic fibrosis: COPD Chronic obstructive pulmonary disease; $\mathrm{PCO}_{2}$ Partial pressure of carbon dioxide

in the canine experiments and in studies of patients whose clinical stability was defined in an inpatient setting (Table 4).

\section{DISCUSSION}

In our study, 18 patients with chronic hypercapnic respiratory disease and without any possible metabolic alkalosis underwent arterial blood gases analyses when they had been without any change in respiratory symptoms or medications for at least one month. Despite having $\mathrm{PCO}_{2}$ levels as high as $77 \mathrm{mmHg}$, all of the patients maintained their $\mathrm{pH}$ at 7.37 or greater, and more than $80 \%$ had a $\mathrm{pH}$ of 7.38 or greater. In patients with chronic hypercapnia, acid-base compensation appears more complete than previously believed.

The limitations of our study include the retrospective design, which can result in incomplete data or confounding, because blood gases are often taken to evaluate symptomatic illnesses (ie, when patients are not stable). Incomplete data was not a problem in the patients reviewed, who form part of a large, prospectively gathered patient database at the Montreal Chest Institute. As well, the indications for blood gas analysis were assessed for home oxygen or rehabilitation programs, both of which emphasize that patients should be stable at the time of the blood gas analysis. The major limitation was the small number of observations. However, statistically significant associations were nevertheless detected, which suggests that the relationships were strongly correlated, because they were detected even with limited power. The small numbers in the study resulted in wide CIs obtained around the estimates of the slope and intercept.

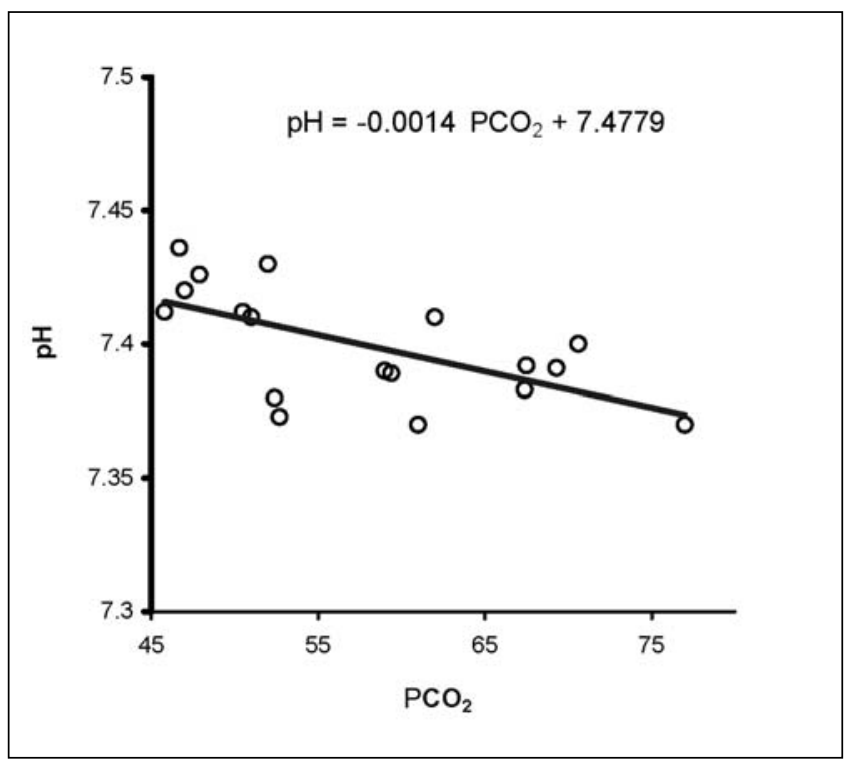

Figure 1) Relationship between $\mathrm{pH}$ and partial pressure of carbon dioxide $\left(\mathrm{PCO}_{2}\right)$ in stable hypercapnic outpatients (estimates for slope regression in 18 patients, $r^{2}=0.39$ )

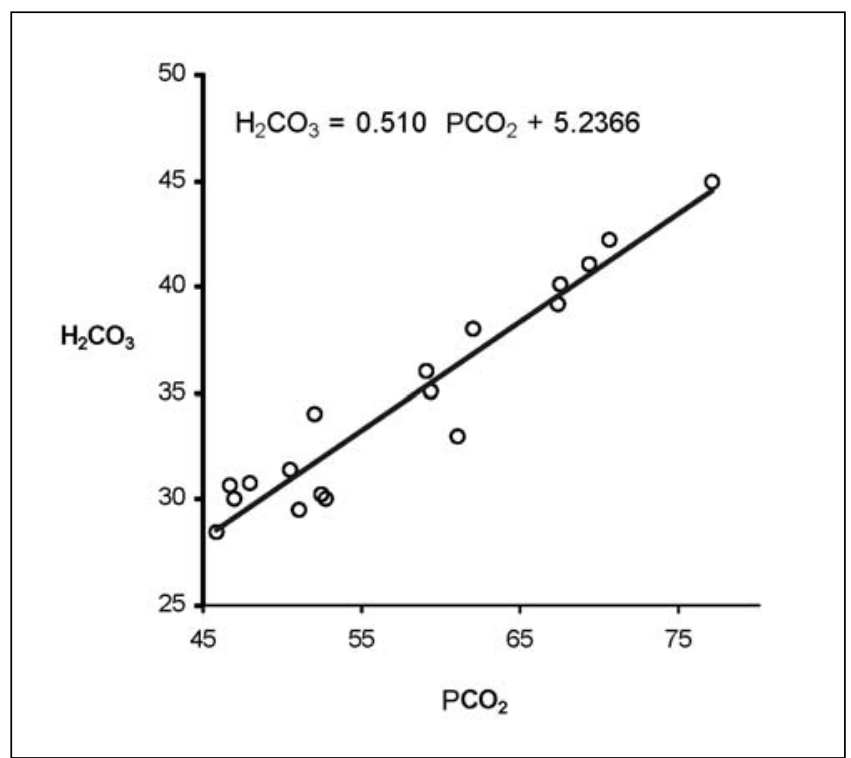

Figure 2) Relationship between bicarbonate $\left(\mathrm{HCO}_{3}\right)$ and partial pressure of carbon dioxide $\left(\mathrm{PCO}_{2}\right)$ in stable hypercapnic outpatients (estimates for slope regression in 18 patients, $r^{2}=0.92$ )

The major strength of our study is that patients were carefully defined as clinically stable for at least one month. As well, patients with disorders likely to cause a superimposed metabolic alkalosis were excluded. Therefore, the findings are of much greater relevance to clinical practice than those from an experimental dog model $(3,4)$ or short term observations in hospitalized patients $(7,10)$. These studies are likely to have underestimated the compensation that patients with chronic respiratory failure may achieve.

The rules for the expected compensation in the setting of acute and chronic respiratory acidosis, which are still applied 
today $(11,12)$, were developed in 1965 from experiments in dogs $(3,4)$. In one of these canine studies $(3), 10$ dogs were exposed to normal atmosphere and then to successive concentrations of $7 \%, 11 \%$ and $17 \%$ carbon dioxide, each for five to seven days. A chronic state was defined as a sustained elevation in the arterial $\mathrm{PCO}_{2}$ for four to five days. This definition was based on previous observations that after four to five days of exposure to a carbon dioxide concentration of $12 \%$, the correction of the $\mathrm{pH}$ appeared to reach a plateau (5).

How applicable are the results of this experiment to patients with slowly progressive lung diseases? First, the experimental procedure of three episodes of acute hypercapnia, each maintained for less than one week, is very different from patients with chronic lung diseases, who develop hypercapnia over a period of years. Also, in the canine study, hypernatremia and significant bicarbonate losses were described in all of the dogs

\section{TABLE 3}

Regression equations for the relationships between partial pressure of carbon dioxide $\left(\mathrm{PCO}_{2}\right), \mathrm{pH}$ and bicarbonate in 18 patients

\begin{tabular}{|c|c|}
\hline \multicolumn{2}{|l|}{ Prediction of $\mathrm{pH}$ from $\mathrm{PCO}_{2}$} \\
\hline Number of observations & 18 \\
\hline Intercept $(95 \% \mathrm{Cl})$ & 7.48 (7.43 to 7.53$)$ \\
\hline Slope $(95 \% \mathrm{Cl})$ & $-0.0014(-0.0023$ to -0.0005$)$ \\
\hline $\mathrm{R}^{2}$ & 0.39 \\
\hline From equation: $\mathrm{pH}$ if $\mathrm{PCO}_{2}=55 \mathrm{mmHg}$ & 7.40 \\
\hline \multicolumn{2}{|c|}{$\begin{array}{l}\text { For } \triangle \mathrm{PCO}_{2} \text { of } 10 \mathrm{mmHg} \text { (eg, } 55 \text { to } 65 \mathrm{mmHg} \text { ), } \\
\text { expected } \mathrm{pH}\end{array}$} \\
\hline \multicolumn{2}{|c|}{$T$ test slope $P=0.006 ;$ Intercept $P=0.0001 ; F$ test for ANOVA $P=0.006$} \\
\hline \multicolumn{2}{|l|}{ Prediction of bicarbonate from $\mathrm{PCO}_{2}$} \\
\hline Number of observations & 18 \\
\hline Intercept $(95 \% \mathrm{Cl})$ & 5.23 (0.58 to 9.9$)$ \\
\hline Slope $(95 \% \mathrm{Cl})$ & $0.51(0.43$ to 0.59$)$ \\
\hline$R^{2}$ & 0.92 \\
\hline \multicolumn{2}{|c|}{ From equation: bicarbonate $(\mathrm{mmol} / \mathrm{L})$ if $\mathrm{PCO}_{2}=55 \mathrm{mmHg} 33$} \\
\hline \multicolumn{2}{|c|}{ For $\triangle \mathrm{PCO}_{2}$ of 10 (eg, 55 to 65 ), } \\
\hline \multicolumn{2}{|c|}{$T$ test slope $P=0.0001 ;$ Intercept $P=0.03 ; F$ test for ANOVA $P=0.0001$} \\
\hline
\end{tabular}

who survived the experiment; however, hypernatremia is not a usual finding in patients with hypercapnia from chronic respiratory failure.

As summarized in Table 3, the relationships between $\mathrm{PCO}_{2}$, bicarbonate and $\mathrm{pH}$ found in the unstable patients in this study were more comparable to the classic dog experiments (3-5) and two studies in humans $(10,13)$. In one of these human studies, 20 patients were evaluated after three days of stability while hospitalized for a respiratory decompensation (10). In the other study, 420 patients with chronic lung disease were evaluated, but chronicity of the respiratory acidosis, patient medications and other confounding factors were not described (13). In a third study among hospitalized hypercapnic patients whose $\mathrm{PCO}_{2}$ levels varied less than $10 \%$ over three days (9), a normal arterial $\mathrm{pH}$ was seen in $87 \%$ of the patients with $\mathrm{PCO}_{2}$ between $46 \mathrm{mmHg}$ and $55 \mathrm{mmHg}$, compared with only $50 \%$ of patients with $\mathrm{PCO}_{2}$ between $56 \mathrm{mmHg}$ and $65 \mathrm{mmHg}$ and $32 \%$ of patients with $\mathrm{PCO}_{2}$ between $66 \mathrm{mmHg}$ and $75 \mathrm{mmHg}$. The results among the stable patients in this study are most similar to the results of a study examining 247 arterial blood gas samples in 106 outpatients (8). In that study, although $\mathrm{pH}$ was not reported, for each increase of $10 \mathrm{mmHg}$ in the $\mathrm{PCO}_{2}$, the bicarbonate level increased by $5.3 \mathrm{mmol} / \mathrm{L}$ - very similar to the findings among stable patients in the present study. Ingram et al (14) studied patients with chronic hypercapnia who had acute changes in their $\mathrm{PCO}_{2}$, with the aim of trying to define the relationship between the change in $\mathrm{pH}$ and increases in the $\mathrm{PCO} 2$ at different baseline PCO2 levels. The demographics of the patients in the steady state were not provided, but they reported the regression equation of the correlation between the steady state hydrogen ion concentration and $\mathrm{PCO}_{2}$ in the patients studied. The correlation was very similar to the one found in the present study. In a recent report (15) examining the strong ion difference in patients with chronic hypercapnia, while not specifically examining the correlation of $\mathrm{pH}$ and $\mathrm{PCO}_{2}$, the authors found that instead of a predicted $\mathrm{pH}$ of 7.355 , they found a measured $\mathrm{pH}$ of 7.372 in a group of 12 patients with a mean $\mathrm{PCO}_{2}$ of $54 \mathrm{mmHg}$.

There is a physiological concept that compensation should never be complete, because then the stimulus to compensate would be lost. This would mean that as the $\mathrm{pH}$ approaches normality, the kidney would no longer be stimulated to retain

TABLE 4

Comparison from the present and earlier studies of regression equations of the relationship of chronic steady state partial pressure of carbon dioxide $\left(\mathrm{PCO}_{2}\right)$ to hydrogen ion concentration $[\mathrm{H+}]$, and predicted bicarbonate concentrations and $\mathrm{pH}$ at two levels of $\mathrm{PCO}_{2}$

\begin{tabular}{|c|c|c|c|c|c|}
\hline Reference & Hydrogen ion regression equation & \multicolumn{2}{|c|}{$\begin{array}{l}\text { Calculated bicarbonate }(\mathrm{mmol} / \mathrm{L}) \text { at a } \mathrm{PCO}_{2} \text { of } \\
55 \mathrm{mmHg} \quad 65 \mathrm{mmHg}\end{array}$} & \multicolumn{2}{|c|}{$\begin{array}{l}\text { Calculated pH at a } \mathrm{PCO}_{2} \text { of } \\
55 \mathrm{mmHg} \quad 65 \mathrm{mmHg}\end{array}$} \\
\hline \multicolumn{6}{|l|}{ Subjects - Patients } \\
\hline Present study (Stable) & {$[\mathrm{H}+]=0.13 \times$ chronic $\mathrm{PCO}_{2}+32.6$} & 33 & 38 & 7.40 & 7.38 \\
\hline Ingram et al (14) & {$[\mathrm{H}+]=0.12 \times$ chronic $\mathrm{PCO}_{2}+33.8$} & 33 & 38 & 7.39 & 7.38 \\
\hline Engel et al (9) & {$[\mathrm{H}+]=0.12 \times$ chronic $\mathrm{PCO}_{2}+35.2$} & 32 & 36 & 7.38 & 7.37 \\
\hline Van Ypersele de Strihou et al (13) & {$[\mathrm{H}+]=0.30 \times$ chronic $\mathrm{PCO}_{2}+26.8$} & 31 & 34 & 7.36 & 7.33 \\
\hline Brackett et al (10) & {$[\mathrm{H}+]=0.24 \times$ chronic $\mathrm{PCO}_{2}+27.2$} & 33 & 36 & 7.39 & 7.37 \\
\hline Present study (Unstable) & {$[\mathrm{H}+]=0.27 \times$ chronic $\mathrm{PCO}_{2}+26.5$} & 33 & 35 & 7.39 & 7.36 \\
\hline \multicolumn{6}{|l|}{ Subjects - Dogs } \\
\hline Schwartz et al (3) & {$[\mathrm{H}+]=0.30 \times$ chronic $\mathrm{PCO}_{2}+26.9$} & 30 & 33 & 7.36 & 7.33 \\
\hline Goldstein et al (4) & {$[\mathrm{H}+]=0.27 \times$ chronic $\mathrm{PCO}_{2}+33.0$} & 28 & 31 & 7.32 & 7.30 \\
\hline
\end{tabular}


bicarbonate and the $\mathrm{pH}$ would reach equilibrium below the normal range. However, in animal studies, the signal to compensate was not the low $\mathrm{pH}$. Instead, the elevated $\mathrm{PCO}_{2}$ directly stimulated the proximal tubule of the kidney to increase bicarbonate reabsorption (16-18). This implies that increased reabsorption of bicarbonate should continue as long as the $\mathrm{PCO}_{2}$ remains elevated, raising interesting questions regarding feedback control of this compensatory response. Chronic adaptation is believed to be entirely due to renal adaptive processes, with increased net acid secretion, primarily in the form of ammonium, reduced reabsorption of chloride and increased reabsorption of bicarbonate ion $(16,18)$. One study found changes in the gastrointestinal handling of chloride ion but little change in renal chloride excretion (19).

\section{CONCLUSIONS}

Although the mechanisms are not understood, renal compensatory mechanisms in chronic respiratory failure appear to be more complete than previously recognized. The clinical implication is important. In a patient with chronic hypercapnia, an arterial $\mathrm{pH}$ below the normal range should suggest the occurrence of worsening respiratory acidosis or new metabolic acidosis.

ACKNOWLEDGEMENTS: The authors thank Drs J Martin, Bernard Unikowsky, Elias Matouk and Jean Bourbeau, as well as Marianne Siok and Catherine Michaud for their assistance in the performance of the project.

\section{REFERENCES}

1. Ganapathy V, Leibach FH. Protons and regulation of biological functions. Kidney Int Suppl 1991;40:4-10.

2. Kurtz I, Maher T, Hulter HN. Effect of diet on plasma acid-base composition in normal humans. Kidney Int 1983;24:670-80.

3. Schwartz WB, Cohen JJ, Brackett NC Jr. The response of extracellular hydrogen ion concentration to graded degrees of chronic hypercapnia: The physiologic limits of the defense of $\mathrm{pH}$. J Clin Invest 1965;44:291-301.
4. Goldstein MB, Gennari FJ, Schwartz WB. The influence of graded degrees of chronic hypercapnia on the acute carbon dioxide titration curve. J Clin Invest 1971;50:208-16.

5. Schwartz WB, Silverman L. The nature of carbon dioxide titration curve in the normal dog. J Clin Invest 1964:43:777-86.

6. Refsum HE. Acid-base disturbances in chronic pulmonary disease. Ann NY Acad Sci 1966;133:142-59.

7. Eichenholz A, Blumentals AS, Walker FE. The pattern of compensatory response to chronic hypercapnia in patients with chronic obstructive pulmonary disease. J Lab Clin Med 1966;68:265-78

8. Dulfano MJ, Ishikawa S. Quantitative acid-base relationships in chronic pulmonary patients during the stable state. Am Rev Respir Dis 1966;93:251-6.

9. Engel K, Dell RB, Rahill WJ, Denning CR, Winters RW. Quantitative displacement of acid-base equilibrium in chronic respiratory acidosis. J Appl Physiol 1968;24:288-95.

10. Brackett NC Jr, Wingo CF, Muren O, Solano JT. Acid-base response to chronic hypercapnia in man. N Engl J Med 1968;280:124-30.

11. Burton DR. Respiratory acidosis. In: Burton Rose, Theodore Post. Physiologic Approach to Acid-Base and Electrolyte Disorders. Columbus: McGraw-Hill Professional, 2000:604-28.

12. Cohen JJ, Kassirer JP. Respiratory acidosis. In: Cohen JJ, Kassirer JP. Acid-Base. Boston: Little Brown \& Company, 1982:307-48.

13. van Ypersele de Strihou C, Frans A. The pattern of respiratory compensation in chronic uraemic acidosis. The influence of dialysis. Nephron 1970;7:37-50.

14. Ingram RH Jr, Miller RB, Tate LA. Acid-base response to acute carbon dioxide changes in chronic obstructive pulmonary disease. Am Rev Respir Dis 1973;108:225-31.

15. Alfaro V, Torras R, Ibanez J, Palacios L. A physical-chemical analysis of the acid-base response to chronic obstructive pulmonary disease. Can J Physiol Pharmacol 1996;74:1229-35.

16. Tannen RL, Hamid B. Adaptive changes in renal acidification in response to chronic respiratory acidosis. Am J Physiol 1985;248:F492-9.

17. Ruiz OS, Qiu YY, Wang LJ, Cardoso LR, Arruda JA. Regulation of renal $\mathrm{Na}-\mathrm{HCO}_{3}$ cotransporter: VIII. Mechanism of stimulatory effect of respiratory acidosis. J Membr Biol 1998;162:201-8.

18. Ruiz OS, Arruda JA, Talor Z. Na-HCO 3 cotransport and $\mathrm{Na}-\mathrm{H}$ antiporter in chronic respiratory acidosis and alkalosis. Am J Physiol 1989;256:F414-20

19. Hansen AC, Wamberg S, Engel K, Kildeberg P. Balance of net base in the rat: adaptation to and recovery from sustained hypercapnia. Scand J Clin Lab Invest 1979;39:723-30. 


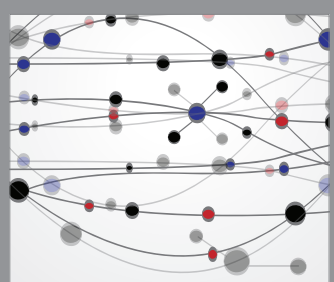

The Scientific World Journal
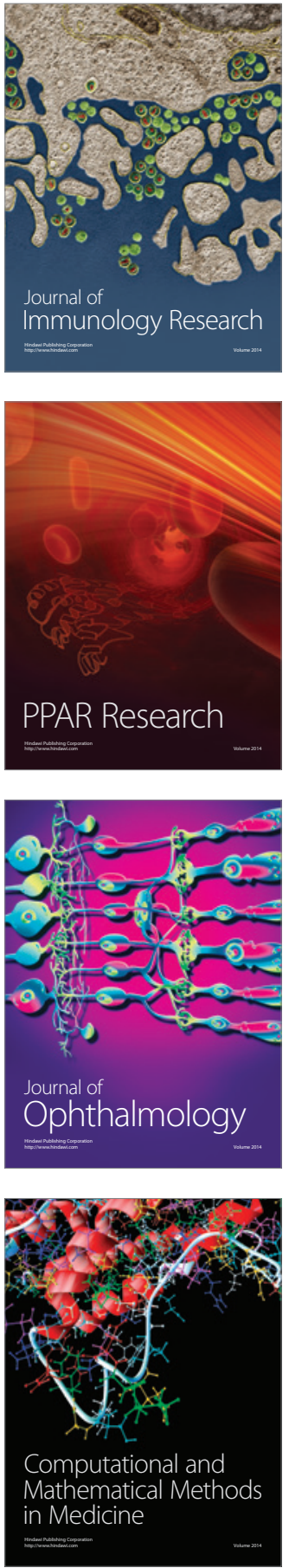

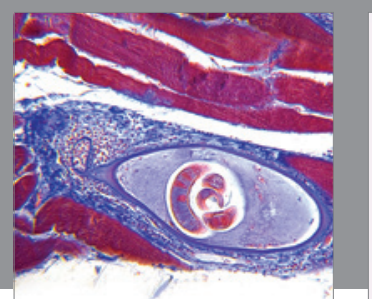

Gastroenterology Research and Practice

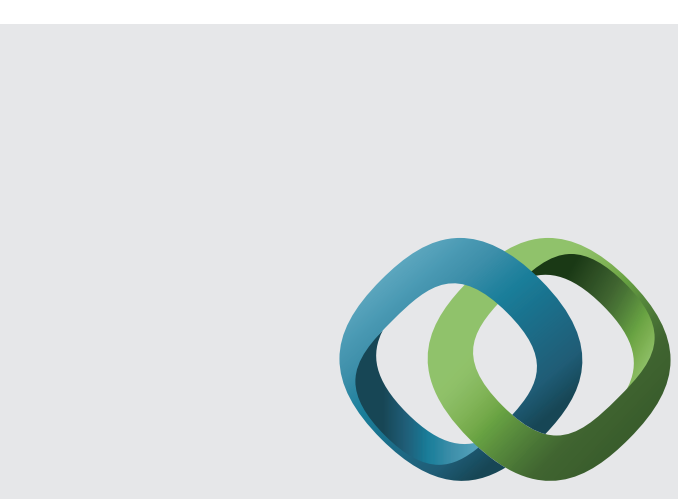

\section{Hindawi}

Submit your manuscripts at

http://www.hindawi.com
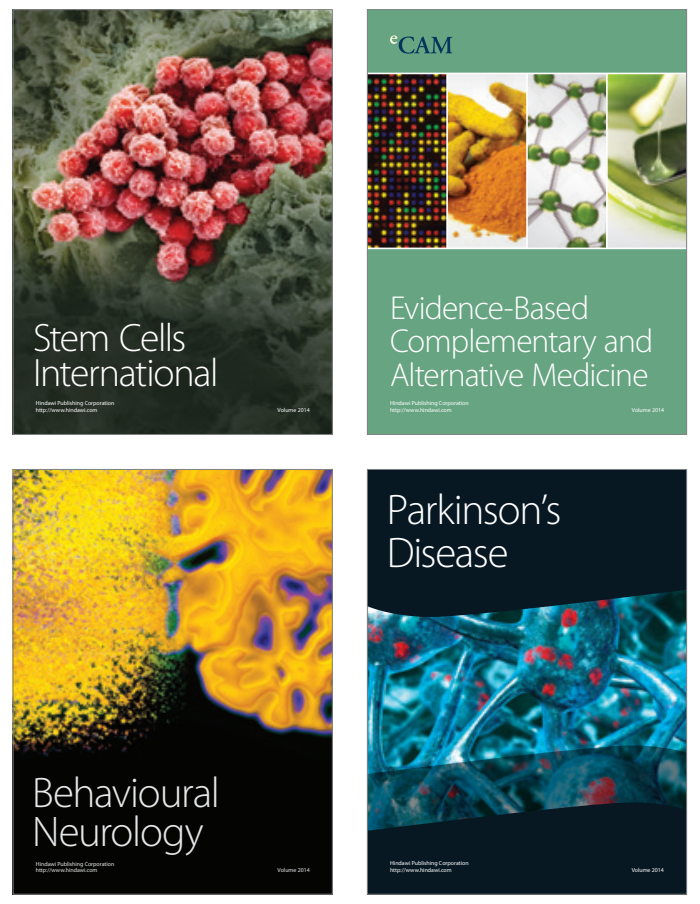
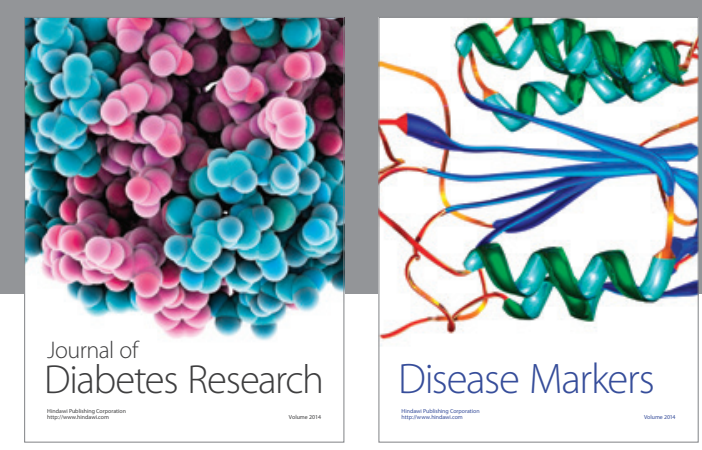

Disease Markers
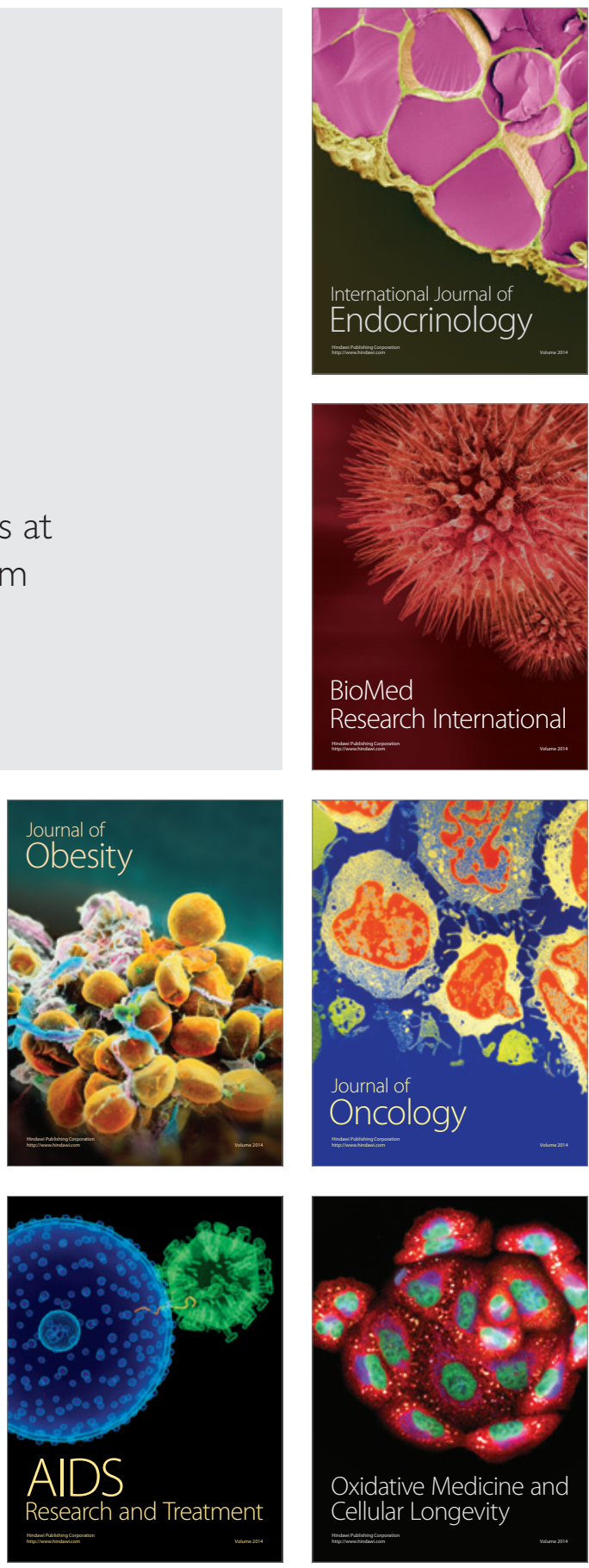